Western University

Scholarship@Western

Medical Biophysics Publications

Medical Biophysics Department

$2-28-2015$

Effect of Taper Design on Trunnionosis in Metal on Polyethylene Total Hip Arthroplasty.

Sok Chuen Tan

Matthew G Teeter

Christopher Del Balso

James L Howard

Brent A Lanting

Follow this and additional works at: https://ir.lib.uwo.ca/biophysicspub

Part of the Medical Biophysics Commons

Citation of this paper:

Tan, Sok Chuen; Teeter, Matthew G; Del Balso, Christopher; Howard, James L; and Lanting, Brent A, "Effect of Taper Design on Trunnionosis in Metal on Polyethylene Total Hip Arthroplasty." (2015). Medical Biophysics Publications. 58.

https://ir.lib.uwo.ca/biophysicspub/58 


\title{
Effect of Taper Design on Trunnionosis in Metal on Polyethylene Total Hip Arthroplasty
}

\author{
Sok Chuen Tan, MBBS, FRCS (Edin) a , Matthew G. Teeter, PhD ${ }^{\mathrm{a}, \mathrm{b}, \mathrm{c}}$, \\ Christopher Del Balso, BSc (Hons), MSc, MBBS ${ }^{\mathrm{a}}$, \\ James L. Howard, MD, MSc, FRCSC ${ }^{a}$, Brent A. Lanting, MD, MSc, FRCSC ${ }^{a}$ \\ a Division of Orthopaedic Surgery, Department of Surgery, Schulich School of Medicine E' Dentistry, University of Western Ontario, London, Ontario, Canada \\ ${ }^{b}$ Department of Medical Biophysics, Schulich School of Medicine E Dentistry, University of Western Ontario, London, Ontario, Canada \\ c Surgical Innovation Program, Lawson Health Research Institute, London, Ontario, Canada
}

\section{A R T I C L E I N F O}

\section{Article history:}

Received 24 December 2014

Accepted 21 February 2015

Available online $\mathrm{xxxx}$

\section{Keywords:}

taper corrosion

taper design

trunnionosis

metal-on-polyethylene

total hip arthroplasty

\begin{abstract}
A B S T R A C T
This study examines how taper design affects corrosion and fretting at the head trunnion surface. All hip prostheses retrieved between 1999 and 2013 with $28 \mathrm{~mm} /+0$ heads were selected, resulting in 44 cobalt-chrome-onpolyethylene implants, representing six taper designs. Mean implantation time: $8.9 \pm 3.7$ years. The femoral head tapers were scored for fretting and corrosion using the Goldberg scale as both a combined score and by three zones (apex, central and base). There was no difference in age $(P=0.34)$, BMI $(P=0.29)$, or implantation time $(P=0.19)$ between taper groups. The $11 / 13$ taper had the highest combined corrosion and fretting score, but no difference ( $P=0.22$ ) between groups for combined scores ( $P=0.22$ for corrosion, $P=0.19$ for fretting). In a zone-specific analysis, the $11 / 13$ taper had highest corrosion score at base zone $(P=0.02)$. Taper design had a significant effect on corrosion at base of trunnion.
\end{abstract}

Crown Copyright (c) 2015 Published by Elsevier Inc. All rights reserved.
Modularity at the head-neck junction in total hip arthroplasty (THA) was introduced only in the late 1980s [1]. Prior to that, hip arthroplasty implants were of monoblock design. Modularity at the head-neck junction offers the surgeon the ability to control offset, limb length and also the option of a different head bearing material with the same stem inventory. However this modularity is not without problems.

Taper corrosion in modular total hip arthroplasty has recently been recognized to be an important issue, with multiple reports of adverse local tissue reactions even in patients with metal-on-polyethylene arthroplasty [2-10]. Cooper et al [3] reviewed ten revised metal-onpolyethylene THA that had elevated serum cobalt and chromium levels, and found visible corrosion at the head-neck junction associated with tissue necrosis and lymphocytic infiltration. Retrieval studies by Dyrkacz et al [11] and Kurtz et al [12] demonstrated significant fretting and corrosion at the head-neck taper interface in metal-onpolyethylene hip arthroplasty. Trunnionosis can therefore be a significant clinical problem.

The primary objective of this study is to examine how taper design affects the presence and magnitude of trunnionosis. The hypothesis is that there is greater trunnionosis with smaller tapers due to increased torque

One or more of the authors of this paper have disclosed potential or pertinent conflicts of interest, which may include receipt of payment, either direct or indirect, institutional support, or association with an entity in the biomedical field which may be perceived to have potential conflict of interest with this work. For full disclosure statements refer to doi: http://dx.doi.org/10.1016/j.arth.2015.02.031.

Reprint requests: Brent A. Lanting, MD, MSc, FRCSC, 339 Windermere Road, London, Ontario, Canada, N6A 5A5. force per surface area. The secondary objectives are to see if a particular zone is more prone to corrosion and fretting, and also if there is association between corrosion and fretting on the trunnion surface.

\section{Materials and Methods}

All retrieved hip prostheses from an implant retrieval lab were retrospectively reviewed after obtaining ethics board approval. These implants were retrieved over the period of 1999 to 2013. To decrease confounders, only $28 \mathrm{~mm}$ head diameters of plus zero length retrieved from metal on polyethylene total hip replacements were selected. All femoral heads were of cobalt-chrome alloy, and had a minimum implantation time of 2 years. This gave a total of 50 sets of retrieved implants. Models with less than three examples of each taper were subsequently excluded from analysis, leaving 44 remaining implants. Demographic details (Table 1), reasons for revision (Table 1) and prosthesis model and taper details (Table 2) were collected from the medical records. Six different tapers from four different manufacturers were included (Fig. 1).

Macroscopic and stereomicroscopic examination of the trunnion surface of 44 femoral heads was performed by two independent observers using the Goldberg damage scoring system [13] (Table 3) for fretting and corrosion. Both observers were blinded to clinical and component data where possible. An optical light microscope (Olympus SZSTS) at $\times 40$ magnification was used to examine each surface in circumferential fashion. The visual appearance of corrosion was defined as regions of discoloration or dullness on the trunnion interface or the presence of black debris, pits or etch marks [13]. The visual appearance 
Table 1

Demographics of Retrieved Prostheses and Reasons for Revision.

\begin{tabular}{ll}
\hline Demographics & Mean $( \pm \mathrm{SD})$ \\
\hline Age at time of revision (years) & $69.4( \pm 13.5)$ \\
Body mass index $\left(\mathrm{kg} / \mathrm{m}^{2}\right)$ & $29.6( \pm 7.3)$ \\
male:female & $20: 24$ \\
Time in vivo (years) & $8.9( \pm 3.7)$ \\
& \\
Reason For Revision & Number \\
Aseptic loosening & 19 \\
Polyethylene wear & 8 \\
Periprosthetic fracture & 7 \\
Instability & 2 \\
Infection & 4 \\
Implant malposition & 1 \\
Others & 3 \\
\hline
\end{tabular}

of fretting was defined as damaged areas with small scars running perpendicular to the circumferential machine lines, or irregular flattened areas, arising from micro-motion between the surfaces [13]. Single, narrow scratches were attributed to assembly or disassembly damage [13].

Each surface of the trunnion was divided into three equal zones, the apex, central and base of the trunnion (Fig. 2). Corrosion and fretting scores were assigned to each of these zones using a scale of 1 (none) to 4 (severe), as described in Table 3. Overall scores for fretting and for corrosion were also calculated by summing the scores from all three zones.

Statistical analysis was performed with the aid of a statistician using SPSS Statistical Program version 21.0. Gaussian distribution of data was checked using Shapiro-Wilk test, and homogeneity of variance was checked using the non-parametric Levene's test. One-way ANOVA was used for comparison between the multiple groups for parametric data, and Kruskal-Wallis test was used for non-parametric data. Spearman's correlation test was used for analysis of correlation of the corrosion and fretting scores. $P$ value of $<0.05$ was determined as the level of statistical significance.

\section{Results}

There was no demographic difference between the taper groups for age at revision $(P=0.343)$, body mass index $(P=0.289)$, or time in vivo $(P=0.185)$. Intraclass correlation coefficient between the two observers for corrosion and fretting scores was 0.993 (95\% CI of 0.985 to 0.996$)$.

There was a significant difference for corrosion within the base zone $(P=0.018)$, with the $11 / 13$ taper having the greatest median corrosion score (Table 2). Comparison between designs for base zone corrosion is shown in Table 4. There was no significant difference between the taper types in central zone $(P=0.212)$ or apex zone $(P=0.839)$. There was also no significant difference between taper types for the sum corrosion score $(P=0.216)$, although the $11 / 13$ taper had the highest median score of 10 (Table 2 ).

The 11/13 taper also had the highest median summed fretting score (Table 2$)$, although no significant difference $(P=0.188)$ was found between tapers. There was also no significant difference between tapers for fretting in the individual base zone $(P=0.100)$, central zone $(P=$ $0.222)$, or apex zone $(P=0.137)$.

There was a significant correlation in the corrosion scores between all zones, including the base and central zones $\left(r^{2}=0.59, P<0.001\right)$, central and apex zones $\left(r^{2}=0.71, P<0.001\right)$ and base and apex zones $\left(r^{2}=0.45, P<0.001\right)$. Similar correlations were also found for the fretting scores across the various zones, including the base and central zones $\left(r^{2}=0.58, P<0.001\right)$; the central and apex zones $\left(r^{2}=0.53\right.$, $P<0.001)$; and the apex and base zones $\left(r^{2}=0.59, P<0.001\right)$. However, there was no significant correlation between the sum corrosion score and sum fretting score $\left(r^{2}=0.24, P=0.12\right)$. No significant difference was found between the sum corrosion score and sum fretting score $(P=0.868)$.

\section{Discussion}

Early reports of trunnionosis in the literature were triggered by adverse soft-tissue reactions and early failures following metal-on-metal arthroplasty of the hip [14-16]. Some studies have demonstrated elevated blood metal ion levels in metal-on-metal THRs as compared to their resurfacing counterparts that do not have a modular head-neck junction [16-18]. Retrieval studies have shown damage at the headneck junction with minimal wear at the bearing surface in patients who underwent revision for metal-on-metal THAs [16,19]. Corrosion at the head-neck taper junction has since been recognized to be a potential clinical concern, even in metal-on-polyethylene THAs [2,3]. Our study is the first retrieval study, to date, that examines the effect of taper design on trunnionosis in metal-on-polyethylene THA in a homogeneous group of $28 \mathrm{~mm}$ cobalt-chrome femoral heads.

Fretting and corrosion observed in tapers are complex issues, occurring due to the interplay of multiple physical and chemical reactions. Gilbert et al [20] described a process of mechanically assisted crevice corrosion, to explain how micromotion and mechanical loading at modular junctions disrupt a protective layer of passive oxide, resulting in crevice corrosion and fretting at the taper interface. He described that shear stresses at the taper interface cause oxide film fractures, exposing fresh metal to oxygen-rich fluid. This oxidizes the underlying metal and thereafter creates an acidic environment in the crevices, destabilizing the passive oxide film and increasing the corrosion rate. This is likely the same process occurring in the trunnions analyzed in this study. The base of the trunnion interface experiences torque forces from the hip articulation that may disrupt the oxide passivity film. The base of the trunnion also has the greatest exposure to the oxygen rich synovial fluid. In our study, taper design showed an effect on corrosion at the base of the trunnion.

Trunnion taper design has changed in recent years. Trunnions in general are becoming shorter to avoid impingement of the prosthetic neck against the acetabular component and to improve range of motion of the prosthetic joint. However what this also means is that the base of the trunnion may often sit within the inside of the taper, especially in the minus heads. This has been shown to potentiate edge loading at the trunnion base [21]. Review of these retrieved implants demonstrated a trunnion design-specific difference in corrosion at the base of the head. This coincides with this study's findings of worse corrosion at the base of the trunnion for a specific taper design.

Table 2

Classification of Various Types of Tapers and Their Corresponding Scores.

\begin{tabular}{|c|c|c|c|c|}
\hline Type & Number of heads & $\begin{array}{l}\text { Median Corrosion Score in Base Zone } \\
\text { of Trunnion (Interquartile Range) }\end{array}$ & $\begin{array}{l}\text { Median Sum Corrosion Score } \\
\text { (Interquartile Range) }\end{array}$ & $\begin{array}{l}\text { Median Sum Fretting Score } \\
\text { (Interquartile Range) }\end{array}$ \\
\hline Smith and Nephew 12/14 (Memphis, TN) & 13 & $2(2-3)$ & $7(6-9)$ & $6(4-9)$ \\
\hline Zimmer 12/14 (Warsaw, IN) & 6 & $2.5(1-4)$ & $6.5(5-10)$ & $7(6-9)$ \\
\hline Depuy $11 / 13$ (Warsaw, IN) & 3 & $4(4-4)$ & $10(8-12)$ & $10(8-12)$ \\
\hline Depuy 14/16 (Warsaw, IN) & 6 & $2(1-3)$ & $6(4-9)$ & $4.5(3-9)$ \\
\hline Stryker 5 degree 38'37" (Kalamazoo, MI) & 5 & $3(2-4)$ & $9(5-12)$ & $7(6-12)$ \\
\hline Stryker 2 degree $52^{\prime}$ (Kalamazoo, MI) & 11 & $3(1-3)$ & $7(5-10)$ & $9(3-12)$ \\
\hline
\end{tabular}




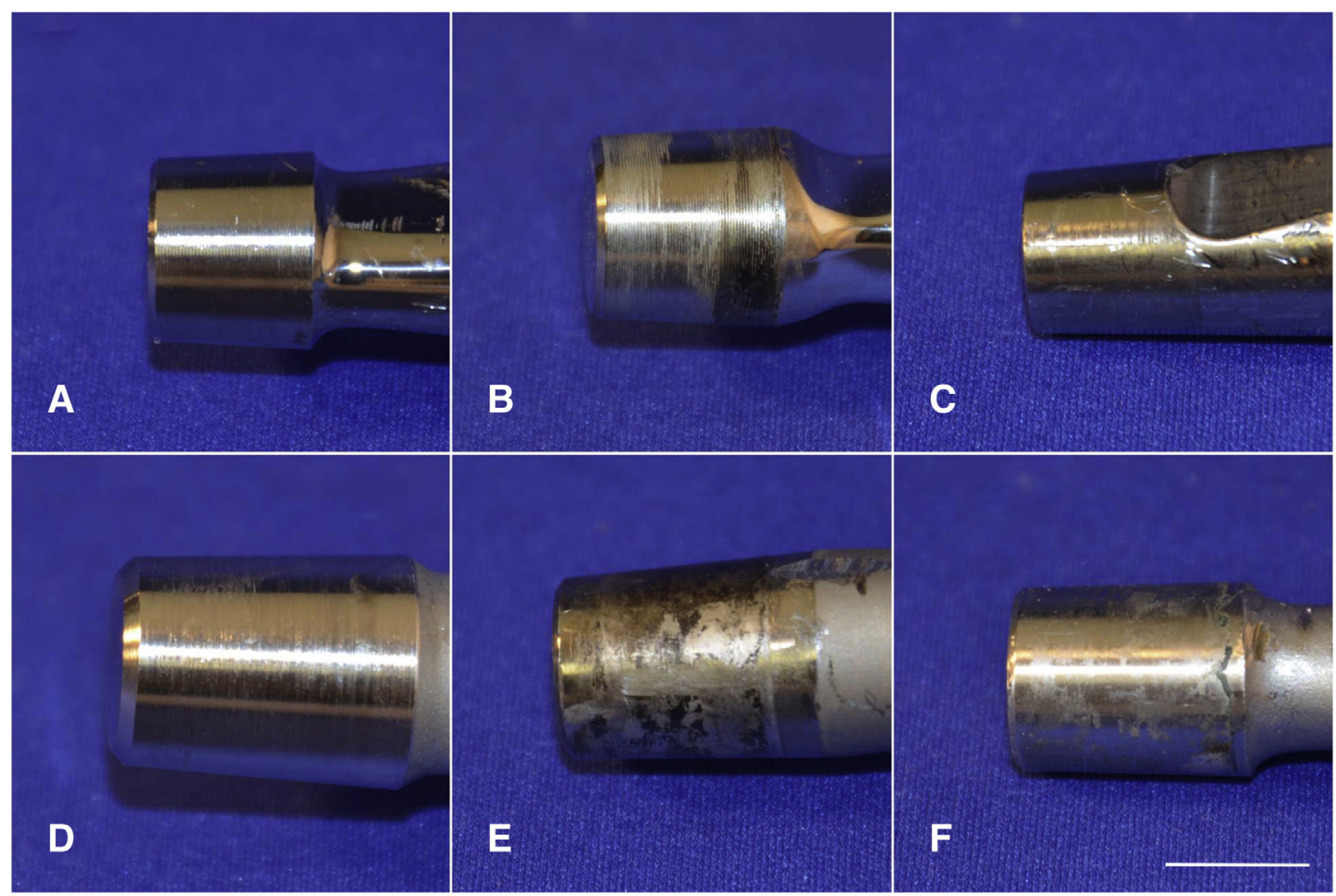

Fig. 1. Various taper designs. (A) Smith and Nephew 12/14, (B) Zimmer 12/14, (C) Depuy 11/13, (D) Depuy 14/16, (E) Stryker 5 38'37", F: Stryker 2 52'. Scale bar is 10 mm.

Taper-trunnion design is also becoming increasingly more narrow to increase range of movement. However a smaller taper translates to a smaller surface area and thus increases the potential for micromotion at the taper-trunnion interface. In our study, the Depuy 11/13 taper, also the narrowest type in the series, demonstrated the highest fretting score at the base zone. This could be due to a higher contact pressure from a smaller surface area. Our finding of a significant difference in corrosion score in Base zone between the various tapers is likely due to the fact that this zone is right at the rim of the head-neck interface, and thus is subjected to fluid ingress which facilitates corrosion. At this most "exterior" zone, there is also higher mechanical loading and greater torque. All these contribute to a more aggressive corrosive environment as suggested by Goldberg [13]. Recently it has also been shown that torque force rather than axial load has an implication on fretting and corrosion [22]. An additional explanation for the greatest damage to the 11/13 taper is that SROM tapers (ie Depuy 11/13 tapers) have asperities on their taper surface related to machine finishes, which could contribute to different contact length against the trunnion and therefore a different force distribution [23]. In a recent study by Porter et al [24], the 11/13 taper was also found to have the least flexural rigidity among the tapers in this study. It is known that flexural rigidity is a risk factor for corrosion as it causes micromotion due to elastic strains $[13,20]$. This could

Table 3

Goldberg's [13] Criteria Used to Define Corrosion and Fretting.

\begin{tabular}{lll}
\hline Score & \multicolumn{1}{c}{ Corrosion Criteria } & \multicolumn{1}{c}{ Fretting Criteria } \\
\hline 1 (none) & $\begin{array}{l}\text { No visible corrosion } \\
<30 \% \text { surface } \\
2 \text { (mild) }\end{array}$ & $\begin{array}{l}\text { No visible signs of fretting } \\
\text { discolored/dull } \\
\text { Band }(\text { s) for fretting scars } \\
\text { across } \leq \text { machine lines }\end{array}$ \\
& $>30 \%$ surface discolored/dull & Band(s) involving \\
& or $<10 \%$ containing black \\
debris, pits or etch marks & $>3$ machine lines \\
& $>10 \%$ surface containing & Several bands of fretting \\
& black debris, pits or etch marks & $\begin{array}{l}\text { scars involving several } \\
\text { machine lines or flattened } \\
\text { areas with nearby fretting scars }\end{array}$ \\
& &
\end{tabular}

be a contributory factor to the finding of a higher zonal corrosion score associated with 11/13 taper in this study.

Taper corrosion has been shown to manifest clinically as adverse local tissue reactions as shown in previous literature [2-10]. In Cooper's series [25], one patient suffered from moderate abductor necrosis due to pseudotumor formation and subsequent dislocations despite an initial revision surgery, requiring a second revision to change to a constrained liner. It is interesting to note that most of the tapers in his series were Zimmer 12/14 [25]. In Cook's series the taper type in both cases was likely Stryker V40 (from Accolade TMZF femoral stem) [2]. Lindgren's [5] case report was also on a pseudotumor from an Accolade TMZF stem. Another case report by Mao et al [6] also described a case of pseudotumor formation from a Stryker Accolade stem in a metal-onpolyethylene THA. So far, there have been no reports of clinical adverse reactions from Depuy 11/13 tapers.

This study has the limitation of small numbers of each taper design. However the study group was homogenous as it compared only $28 \mathrm{~mm}$ plus zero heads articulating with a polyethylene surface for a minimum of 2 years. As such, this study has the largest number in the literature to date looking at this particular question. That limited the effect of size of the femoral head or neck length affecting the torque at the taper junction. Another limitation is that the methodology to assess the extent

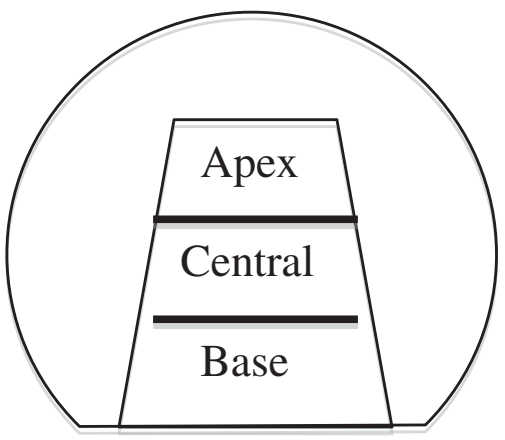

Fig. 2. The apex, central and base zones of a trunnion. 
Table 4

$P$ values of the Post-Hoc Comparison Analysis Between the Various Taper Types for Corrosion in the Base Zone.

\begin{tabular}{|c|c|c|c|c|c|c|}
\hline Taper types & Smith and Nephew $12 / 14$ & Zimmer 12/14 & Depuy $11 / 13$ & Depuy $14 / 16$ & Stryker $5^{\circ} 38^{\prime} 37^{\prime \prime}$ & Stryker $2^{\circ} 52^{\prime}$ \\
\hline Smith and Nephew $12 / 14$ & & 0.449 & $0.006^{\mathrm{a}}$ & 0.360 & $0.043^{\mathrm{a}}$ & 0.382 \\
\hline Zimmer $12 / 14$ & 0.449 & & $0.041^{\mathrm{a}}$ & 0.238 & 0.383 & 0.869 \\
\hline Depuy $11 / 13$ & $0.006^{\mathrm{a}}$ & $0.041^{\mathrm{a}}$ & & $0.016^{\mathrm{a}}$ & $0.050^{\mathrm{a}}$ & $0.006^{\mathrm{a}}$ \\
\hline Depuy $14 / 16$ & 0.360 & 0.238 & $0.016^{\mathrm{a}}$ & & $0.035^{\mathrm{a}}$ & 0.194 \\
\hline Stryker 5 degree $38^{\prime} 37^{\prime \prime}$ & $0.043^{\mathrm{a}}$ & 0.383 & $0.050^{\mathrm{a}}$ & $0.035^{\mathrm{a}}$ & & 0.214 \\
\hline Stryker 2 degree $52^{\prime}$ & 0.382 & 0.869 & $0.006^{\mathrm{a}}$ & 0.194 & 0.214 & \\
\hline
\end{tabular}

a Significant values.

of fretting and corrosion is subjective. However we are using a scoring system that is well recognized [13] and also shown to be correlated with material loss [26].

Trunnionosis is a clinical problem of significant controversy. In this cohort of retrieved femoral heads controlled for head dimensions and articular properties, trunnion design was found to have a significant effect on the amount of corrosion at the base of the head trunnion, with the narrowest taper 11/13 performing the worst. How the mechanical and biologic factors interact with taper design needs further review and discussion. There has been some literature implicating the effect of edge loading [27-29] and low clearance [27] on failure of metal-onmetal hip arthroplasty. The effect on metal-on-polyethylene THAs is less clear. Although in a review article by Harris et al [30], it seems that edge loading does not accelerate wear at the articulation in metal-onpolyethylene THAs, we do not yet know of its effect on the head-neck taper interface. When edge loading is coupled with certain taper designs such as one with a low taper angle, then the shear forces may be sufficiently high to manifest as clinically significant taper corrosion. This may be a question that future in vitro or large retrieval studies can answer.

\section{Acknowledgement}

I would to express my gratitude to Ms Lyndsay Somerville for her assistance in statistical work.

\section{References}

1. Callaghan JJ, Rosenberg AG, Rubash HE, et al. The adult hip. Philadephia: Lippincott Williams \& Wilkins; 2007

2. Cook RB, Bolland BJ, Wharton JA, et al. Pseudotumour formation due to tribocorrosion at the taper interface of large diameter metal on polymer modular total hip replacements. J Arthroplasty 2013;28(8):1430.

3. Cooper HJ, Della Valle CJ, Berger RA, et al. Corrosion at the head-neck taper as a cause for adverse local tissue reactions after total hip arthroplasty. J Bone Joint Surg Am 2012;94(18):1655.

4. Scully WF, Teeny SM. Pseudotumor associated with metal-on-polyethylene total hip arthroplasty. Orthopedics 2013;36(5):e666.

5. Lindgren JU, Brismar BH, Wikstrom AC. Adverse reaction to metal release from a modular metal-on-polyethylene hip prosthesis. J Bone Joint Surg (Br) 2011;93(10): 1427.

6. Mao X, Tay GH, Godbolt DB, et al. Pseudotumor in a well-fixed metal-onpolyethylene uncemented hip arthroplasty. J Arthroplasty 2012;27(3):493e13.

7. Walsh AJ, Nikolaou VS, Antoniou J. Inflammatory pseudotumor complicating metalon-highly cross-linked polyethylene total hip arthroplasty. J Arthroplasty 2012; 27(2):324e5.

8. Svensson O, Mathiesen EB, Reinholt FP, et al. Formation of a fulminant soft-tissue pseudotumor after uncemented hip arthroplasty. A case report. J Bone Joint Surg Am 1988;70(8):1238.
9. Watanabe H, Takahashi K, Takenouchi K, et al. Pseudotumor and deep venous thrombosis due to crevice corrosion of the head-neck junction in metal-on-polyethylene total hip arthroplasty. J Orthop Sci 2014 Oct 27 [Epub ahead of print].

10. Shulman RM, Zywiel MG, Gandhi R, et al. Trunnionosis: the latest culprit in adverse reactions to metal debris following hip arthroplasty. Skeletal Radiol 2015;44(3):433.

11. Dyrkacz RM, Brandt JM, Ojo OA, et al. The influence of head size on corrosion and fretting behaviour at the head-neck interface of artificial hip joints. J Arthroplasty 2013; 28(6): 1036 .

12. Kurtz SM, Kocagoz SB, Hanzlik JA, et al. Do ceramic femoral heads reduce taper fretting corrosion in hip arthroplasty? A retrieval study. Clin Orthop Relat Res 2013; 471(10):3270.

13. Goldberg JR, Gilbert JL, Jacobs JJ, et al. A multicenter retrieval study of the taper interfaces of modular hip prostheses. Clin Orthop Relat Res 2002;401:149.

14. Pandit H, Glyn-Jones S, McLardy-Smith P, et al. Pseudotumours associated with metal-on-metal hip resurfacings. J Bone Joint Surg (Br) 2008;90(7):847.

15. Langton DJ, Jameson SS, Joyce TJ, et al. Early failure of metal-on-metal bearings in hip resurfacing and large-diameter total hip replacement: A consequence of excess wear. J Bone Joint Surg (Br) 2010;92(1):38.

16. Langton DJ, Jameson SS, Joyce TJ, et al. Accelerating failure rate of the ASR total hip replacement. J Bone Joint Surg (Br) 2011;93(8):1011.

17. Garbuz DS, Tanzer M, Greidanus NV, et al. The John Charnley Award: metal-on-metal hip resurfacing versus large-diameter head metal-on-metal total hip arthroplasty: a randomized clinical trial. Clin Orthop Relat Res 2010;468(2):318.

18. Beaule PE, Kim PR, Hamdi A, et al. A prospective metal ion study of large-head metalon-metal bearing: a matched-pair analysis of hip resurfacing versus total hip replacement. Orthop Clin North Am 2011;42(2):251 [ix].

19. Bolland BJ, Culliford DJ, Langton DJ, et al. High failure rates with a large-diameter hybrid metal-on-metal total hip replacement: clinical, radiological and retrieval analysis. J Bone Joint Surg (Br) 2011;93(5):608.

20. Gilbert JL, Buckley CA, Jacobs JJ. In vivo corrosion of modular hip prosthesis components in mixed and similar metal combinations. The effect of crevice, stress, motion, and alloy coupling. J Biomed Mater Res 1993;27(12):1533.

21. Langton DJ, Sidaginamale R, Lord JK, et al. Taper junction failure in large-diameter metal-on-metal bearings. Bone Joint Res 2012;1(4):56.

22. Jauch SY, Coles LG, Ng LV, et al. Low torque levels can initiate a removal of the passivation layer and cause fretting in modular hip stems. Med Eng Phys 2014;36(9):1140.

23. Munir S, Walter WL, Walsh WR. Variations in the trunnion surface topography between different commercially available hip replacement stems. J Orthop Res 2015;33(1):98.

24. Porter DA, Urban RM, Jacobs JJ, et al. Modern trunnions are more flexible: a mechanical analysis of THA taper designs. Clin Orthop Relat Res 2014;472(12):3963.

25. Cooper HJ, Urban RM, Wixson RL, et al. Adverse local tissue reaction arising from corrosion at the femoral neck-body junction in a dual-taper stem with a cobalt-chromium modular neck. J Bone Joint Surg Am 2013;95(10):865.

26. Hothi HS, Matthies AK, Berber R, et al. The reliability of a scoring system for corrosion and fretting, and its relationship to material loss of tapered, modular junctions of retrieved hip implants. J Arthroplasty 2014;29(6):1313.

27. Underwood RJ, Zografos A, Sayles RS, et al. Edge loading in metal-on-metal hips: low clearance is a new risk factor. Proc Inst Mech Eng H 2012;226(3):217.

28. Matthies A, Underwood R, Cann P, et al. Retrieval analysis of 240 metal-on-metal hip components, comparing modular total hip replacement with hip resurfacing. J Bone Joint Surg (Br) 2011;93(3):307.

29. Witt F, Bosker BH, Bishop NE, et al. The relation between titanium taper corrosion and cobalt-chromium bearing wear in large-head metal-on-metal total hip prostheses: a retrieval study. J Bone Joint Surg Am 2014;96(18):e157.

30. Harris WH. Edge loading has a paradoxical effect on wear in metal-on-polyethylene total hip arthroplasties. Clin Orthop Relat Res 2012;470(11):3077. 